\title{
Bankruptcy Prediction By Using The Grover Method
}

\author{
Fitriani Saragih ${ }^{1}$, Elizar Sinambela ${ }^{2}$ dan Eka Nurmala Sari ${ }^{3}$ \\ \{fitrianisaragih@umsu.ac.id ${ }^{1}$ \} \\ 1,2,3University of Muhammadiyah Sumatera Utara, Jl. Kapten Mukhtar Basri No. 3 Medan, Indonesia
}

\begin{abstract}
This study aimed to determine and analyze prediction of bankruptcy in telecommunication companies listed on the Indonesia Stock Exchange by using the Grover method. The approach of this research was a descriptive approach. The population in this study was telecommunication companies listed on the Indonesia Stock Exchange, namely five companies. The sampling technique in this study was purposive sampling, so that four selected companies were sampled. Data collection technique in this study was documentation technique. The data analysis technique in this study was descriptive, using the Grover method to predict bankruptcy. The Grover method formula was: 1,650X1 + $3,404 \mathrm{X} 3-0,016 \mathrm{ROA}+0,057$. This study used three financial ratios, including: Working Capital to Total Assets (X1), Earning Before Interest and Tax (X3), and Return On Assets (ROA). The Grover method categorized companies as bankrupt with G-Score was equal to or less than $-0.02(\mathrm{G} \leq-0.02)$. G-Score for companies which were not bankrupt was equal to or more than 0.01 (G 10.01 ). Companies with G-Score between the upper and lower limits were in the gray area. The findings showed that company that never had a GScore bankrupt category was PT Telekomunikasi Indonesia Tbk, while companies that had had a G-Score bankrupt category were PT Indosat Tbk from 2013 to 2017, PT Smartfren Telecom Tbk from 2012 to 2017, and PT XL Axiata Tbk from 2015 to 2017. And there had been an increase in the number of companies which were predicted to experience bankruptcy.
\end{abstract}

Keywords: Bankruptcy Prediction, Grover Method.

\section{Introduction}

Competition in the business world is getting tougher, especially in the telecommunication sector. This has an impact on telecommunication companies that have begun to close their services, such as Esia and Flexi. This of course must be a lesson for other telecommunication companies, especially for telecommunication companies whose performances were not good enough to immediately make improvements, so they will not experience bankruptcy.

Bankruptcy is something that is greatly avoided by all companies. Many factors can lead to bankruptcy, and one of them is financial difficulty. Financial distress models need to be developed as a model of an early warning system.Such an effort is intended to anticipate the conditions that can lead to the bankruptcyof the company (Husein and Pambekti, 2014), and financial distress are not only measured by financial and non-financial variables (Fatmawati, 2012). The failure Prediction models reviewed inthis section may be broadly grouped into two homogeneous categories: developed country models and developing country models (Altman, Edward I, 1997).

Bankruptcy prediction is a method to find out the possibility of a company going bankrupt or not. An analysis of bankruptcy is carried out to get an early warning of bankruptcy (signs of early bankruptcy). The earlier the signs of bankruptcy are seen, the better the management to be able to make improvements". Based on this, it can be concluded that the 
prediction of bankruptcy is very beneficial for stakeholders, because it provides very important information to stakeholders in making decisions.

In this study, the method used to predict bankruptcy was the Grover method. Grover method is a method used to predict bankruptcy by designing and reassessing the Altman ZScore method. Jeffrey S. Grover used samples according to the Altman Z-Score model in 1968, adding 13 new financial ratios. The sample used was 70 companies, with 35 companies that went bankrupt and 35 companies that did not go bankrupt from 1982 to 1996. To predict bankruptcy using the Grover method, financial statements are needed as data which will be subsequently processed.

As for the cause of why the method used to predict the bankruptcy of Grover in this study because the method alays superior than Grover methods of the others. For example, (Prihantini, 2013) stated that "Grover's model has a high level of accuracy $(100 \%)$, then Springate and Zmijewski (90\%), and Altman (80\%)".

\section{Theoretical Framework}

\subsection{Bankruptcy}

Bankruptcy is a condition when the company has insufficient funds to run its business (Salim, 2017).. Defenisition other bankruptcy according to (Jabeur, 2017) a situation in which cash flows generated by companies fail to meet obligations toward their financial and nonfinancial partners

The characteristics of companies going through bankruptcy according to (Nirmala, 2016) are as follows:

1) Declining in Industry

2) The Company Conducts Large-scale Restructuring

3) The Company Brings Consultants

4) The Company start looking for Employees Over Power

5) The company can be acquited by another company obtained

6) Company starts cutting costs

7) Company finance is in Difficulty

From the point of view of the stock, the company can be declared bankrupt although it may still generate sufficient cash flow, or have good prospects in the future. that the problem can lead bankruptcy is short-term financial difficulties which imply to non-solvable difficulties. That is companies have difficulties in repaying their debt due to limited assets. The non-solvable difficulties cause liquidation and reorganization for the companies (Nugroho, 2018).

To find out whether the company will experience bankruptcy or not, an indicator or data is needed to predict bankruptcy. Financial ratios published by the Indonesia Stock Exchange (IDX) and used that information to make investment decisions need to look at bankruptcy levels and health (Warastuti, Lucky and Sitinjak, 2014)

\subsection{Bankruptcy Prediction Based on the Grover Method}

Every company must have the possibility of bankruptcy. Companies that have poor performance, the possibility of bankruptcy is very big. To anticipate this, the manager must make improvements. One of the initial stages that managers can do to improve company performance is by predicting bankruptcy. 
The sign of bankruptcy can be detected from the finacial statement (Dewi Anggraini, 2017).

An analysis of bankruptcy is carried out to obtain an early warning of bankruptcy (the initial characteristics of bankruptcy). The earlier the characteristics of bankruptcy are known, the better it is for management to make improvements.

So, it can be concluded that the prediction of bankruptcy is a method to find out whether the company will go bankrupt or not. The earlier the characteristics of bankruptcy are known, the better it is for management to make improvements.

The Grover method is a method used to predict bankruptcy, this method was created by Jeffrey S. Grover by designing and reassessing the Altman Z-Score method. Jeffrey S. Grover used samples according to the Altman Z-Score model in 1968, by adding 13 new financial ratios. The sample used was 70 companies with 35 companies that went bankrupt and 35 companies that did not go bankrupt, from 1982 to 1996 (Fredy, 2018). The following is the Grover method formula cited from (Aminian, 2016):

$G$-Score $=1,650 \mathrm{X} 1+3,404 \mathrm{X} 2-0,016 \mathrm{ROA}+0,057$

Description:

$\mathrm{X} 1=$ Working Capital $/$ Total Assets

X3 = Earning Before Interest and Tax / Total Assets

$\mathrm{ROA}=$ Net Income $/$ Total Assets

The Grover method categorizes companies in bankruptcy with G-Score is equal to or less than $-0.02(\mathrm{G} \leq-0.02)$, while the company is not bankrupt with G-Score is equal to or more than 0.01 ( $\mathrm{G} \geq 0$, (Puspitasari, 2018). Companies with G-Score between the upper and lower limits are in the gray area. The data used to predict bankruptcy are financial statements. Financial statements according to (Primasari, 2018): "Financial statements are used as a form of accountability to the public to monitor performance and evaluate management, provide a basis for observing trends between time periods, achievement of the stated goals and compare them with the performance of other similar organizations if any and allow outsiders to obtain cost information goods and services received and to asses the efficiency and effectiveness of the use of organizational resources". There are several financial ratios used in predicting bankruptcy using the Grover method. The financial ratios are as follows:

a. Working Capital to Total Assets (X1)

b. Earning Before Interest and Tax (X2)

c. Return On Assets (ROA)

\subsection{Analytical Framework}

In this study, the writers predicted bankruptcy in telecommunications companies listed on the Indonesia Stock Exchange from 2012 to 2017. These companies consist of four companies namely PT Indosat Tbk, PT Smartfren Telecom Tbk, PT Telekomunikasi Indonesia Tbk, dan PT XL Axiata Tbk .

The writers firstly collected the statements of financial position and income statement of telecommunication companies listed on the Indonesia Stock Exchange from 2012 to 2017 through the official website of the Indonesia Stock Exchange in www.idx.co.id. Then by the financial statement data, the writers calculated bankruptcy predictions using the Grover method. After the calculation results were obtained, the author drew conclusions (were the companies predicted to be in bankruptcy, gray area, or not bankrupt) by adjusting the results of these calculations with bankruptcy criteria according to the Grover method.

The Grover method categorized companies in bankruptcy with G-Score were equal to or less than $-0.02(\mathrm{G} \leq-0.02)$, while the companies were not bankrupt with G-Score were equal 
to or more than $0.01(\mathrm{G} \geq 0,01)$. Companies with $\mathrm{G}$-Score between the upper and lower limits were in the gray area.

\section{Research Methods}

The research approach used was a descriptive approach. The descriptive approach is a study that tests and analyzes variables independently to find out in depth about particular variables. In this study, researchers tried to test and analyze bankruptcy predictions using the Grover method on telecommunication companies listed on the Indonesia Stock Exchange.

The approach of this research was a descriptive approach. The population in this study were telecommunication companies listed on the Indonesia Stock Exchange which consisted of five companies. The sampling technique in this study was purposive sampling, so that four companies were sampled. Data collection techniques in this study were documentation techniques. The data analysis technique in this study was descriptive, and by using the Grover method to predict bankruptcy. The Grover method formula was: 1,650X1 + 3,404X2 0,016ROA + 0,057. This study used three financial ratios, including: Working Capital to Total Assets (X1), Earning Before Interest and Tax (X2), and Return On Assets (ROA). The Grover method categorized companies in bankruptcy with G-Score was equal to or less than -0.02 (G $\leq-0.02$ ). G-Score for companies that were not bankrupt was equal to or more than 0.01 (G 1 0.01). Companies with G-Score between the upper and lower limits were in the gray area.

\subsection{Research Findings}

\subsubsection{Working Capital to Total Assets (X1)}

Working Capital to Total Assets (X1) is a financial ratio that shows the company's ability to generate net working capital from all assets owned by the company. If the value of the financial ratio is negative, it is likely that the company will have difficulty in repaying its short-term liabilities by using its current assets. Conversely, if the value of the financial ratio is positive, the company will be easy to pay off its short-term liabilities by using its current assets. This financial ratio is part of the liquidity ratio.

$\mathrm{X} 1=$ (Current Assets - Short-term Liabilities) / Total Aset

Table 1. Working Capital to Total Assets (X1)

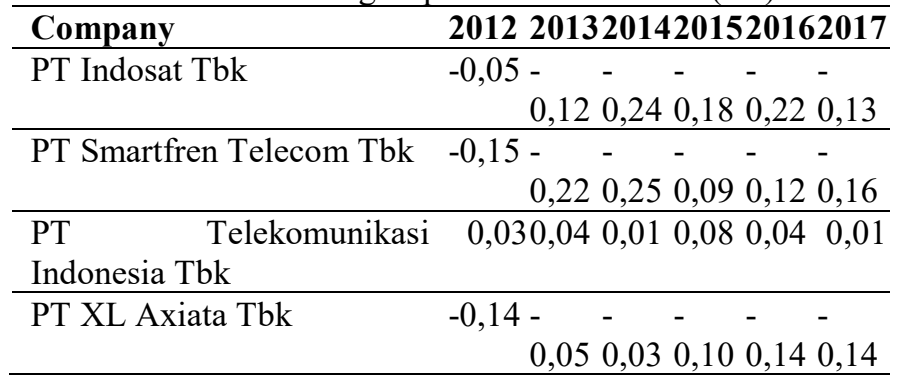




\subsubsection{Earnig Before Interest and Tax to Total Assets (X2)}

Earning Before Interest and Tax (X2) is a financial ratio that shows the company's ability to generate profits before interest and taxes from all assets owned by the company. This financial ratio is part of the profitability ratio.

X2 = Earning before interest and tax / Total Assets

Table 2. Earnig Before Interest and Tax to Total Assets (X2)

\begin{tabular}{lcccccc}
\hline Company & $\mathbf{2 0 1 2}$ & $\mathbf{2 0 1 3}$ & $\mathbf{2 0 1 4}$ & $\mathbf{2 0 1 5}$ & $\mathbf{2 0 1 6}$ & $\mathbf{2 0 1 7}$ \\
\hline PT Indosat Tbk & 0,06 & 0,03 & 0,01 & 0,04 & 0,08 & 0,08 \\
\hline PT Smartfren Telecom Tbk & $-0,11$ & $-0,10$ & $-0,05$ & $-0,06$ & $-0,09$ & $-0,02$ \\
\hline PT Telekomunikasi Indonesia Tbk & 0,23 & 0,22 & 0,21 & 0,20 & 0,22 & 0,21 \\
\hline PT XL Axiata Tbk & 0,13 & 0,07 & 0,03 & 0,02 & 0,0002 & 0,00 \\
\hline
\end{tabular}

\subsubsection{Return On Assets (ROA)}

Return On Assets (ROA) is a financial ratio that shows the ability of a company to generate net income or profit after interest and tax from all assets owned by the company. This financial ratio is part of the profitability ratio.

ROA $=$ Net Profit $/$ Total Assets

Table 3. Return On Assets (ROA)

\begin{tabular}{|c|c|c|}
\hline Company & 2012201320142015 & 20162017 \\
\hline PT Indosat Tbk & $0,01-0,05-0,04-0,02$ & $0,020,02$ \\
\hline PT Smartfren Telecom Tbk & $-0,11-0,16-0,08-0,08$ & $-0,09-0,03$ \\
\hline $\begin{array}{l}\text { PT Telekomunikas } \\
\text { Indonesia Tbk }\end{array}$ & i0,12 $0,110,100,09$ & $0,110,11$ \\
\hline PT XL Axiata Tbk & $\begin{array}{r}0,08 \quad 0,03-0,01- \\
0,0004\end{array}$ & $0,010,01$ \\
\hline
\end{tabular}

\subsubsection{Bankruptcy Predictions using the Grover Method (G-Score)}

This method was used to predict the bankruptcy of a company by using financial statements as data that was processed to predict bankruptcy. This method was founded by Jeffrey S. Grover. The formula of G-Score was as follow:

$G$-Score $=1,650 \mathrm{X} 1+3,404 \mathrm{X} 2-0,016 \mathrm{ROA}+0,057$

Description:

$\mathrm{X} 1$ = Working Capital / Total Assets

X3 = Earning Before Interest and Tax / Total Assets

ROA $=$ Net Income $/$ Total Assets

\subsection{Discussion}

\subsubsection{Predicted companies would go bankrupt and not go bankrupt}

Based on the results of Grover's research method, companies which were predicted to experience bankruptcy were found. The following was a G-Score table on telecommunication companies listed on the Indonesia Stock Exchange from 2012 to 2017. 
Table 4. G-Score from 2012 to 2017

\begin{tabular}{lcccccc}
\hline Company & $\mathbf{2 0 1 2}$ & $\mathbf{2 0 1 3}$ & $\mathbf{2 0 1 4}$ & $\mathbf{2 0 1 5}$ & $\mathbf{2 0 1 6}$ & $\mathbf{2 0 1 7}$ \\
\hline PT Indosat Tbk & 0,18 & $-0,04$ & $-0,3$ & $-0,1$ & $-0,03$ & $-0,04$ \\
\hline PT Smartfren Telecom Tbk & $-0,56$ & $-0,64$ & $-0,52$ & $-0,29$ & $-0,45$ & $-0,28$ \\
\hline PT Telekomunikasi Indonesia Tbk & 0,89 & 0,87 & 0,79 & 0,87 & 0,87 & 0,80 \\
\hline PT XL Axiata Tbk & 0,28 & 0,21 & 0,10 & $-0,04$ & $-0,17$ & $-0,17$ \\
\hline
\end{tabular}

$\mathrm{B}=$ Bankrupt $(\mathrm{G} \leq-0,02)$

$\mathrm{TB}=$ Not bankrupt $(\mathrm{G} \geq 0,01)$

In 2012, the company predicted to experience bankruptcy was PT Smartfren Telecom Tbk, while companies that were predicted not to go bankrupt were PT Indosat Tbk, PT Telekomunikasi Indonesia Tbk, and PT XL Axiata Tbk .

In 2013 to 2014, there was only one additional company which was predicted to experience bankruptcy. The company was PT Indosat Tbk. So companies which were predicted to experience bankruptcy were PT Indosat Tbk and PT Smartfren Telecom Tbk. While companies which were not predicted to experience bankruptcy were PT Telekomunikasi Indonesia Tbk and PT XL Axiata Tbk.

From 2015 to 2017, there was an additional company that was predicted to experience bankruptcy. The company was PT XL Axiata Tbk. So companies which were predicted to experience bankruptcy were PT Indosat Tbk, PT Smartfren Telecom Tbk, and PT XL Axiata Tbk. While company which was not predicted to experience bankruptcy was PT Telekomunikasi Indonesia Tbk.

Based on the description, it could be seen that in the last five years companies which were predicted to experience bankruptcy were PT Indosat Tbk (2013 to 2017), PT Smartfren Telecom Tbk (2012 to 2017), and PT XL Axiata Tbk (2015 to 2017), while company that had never been predicted to experience bankruptcy was PT Telekomunikasi Indonesia Tbk. The financial difficulties faced by companies which were predicted to experience bankruptcy must be corrected immediately, because if they were not immediately corrected, the company would actually experience bankruptcy. This was supported by (Espacios, Autores and Pakdaman, 2018), models grover is better able to predict financial crisis.

\subsubsection{Companies Growth in Bankruptcy Prediction}

The following is a graph of the growth of telecommunication companies listed on the Indonesia Stock Exchange from 2012 to 2017 which were predicted to go bankrupt. 


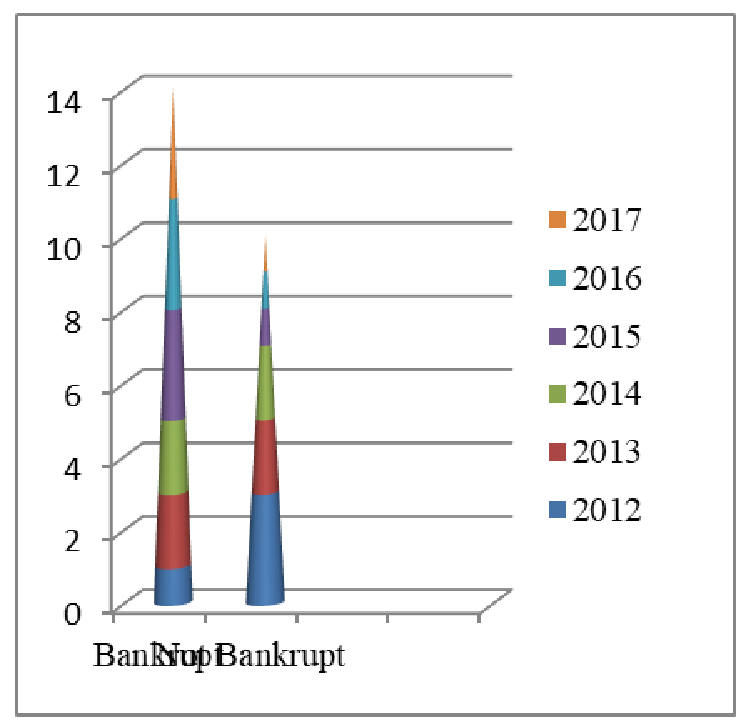

Fig.1. Company's Growth in Bankruptcy prediction

Based on Figure 1, it could be seen that in the last five years there had been an increase in the number of companies which were predicted to experience bankruptcy. In 2012 alone, the company predicted to experience bankruptcy was PT Smartfren Telecom Tbk. Then it experienced an increase in 2013 involving PT Indosat Tbk and in 2015 involving PT XL Axiata Tbk. In the last five years there had been three companies which were predicted to experience bankruptcy, and one company which had never been predicted to experience bankruptcy. The companies which had been predicted to experience bankruptcy were PT Indosat Tbk, PT Smartfren Telecom Tbk, PT XL Axiata Tbk, while company which was never predicted to experience bankruptcy was PT Telekomunikasi Indonesia Tbk.

\subsubsection{G-Score Growth in Telecommunication Companies}

The following was a picture of G-Score growth in telecommunications companies listed on the Indonesia Stock Exchange from 2012 to 2017. 


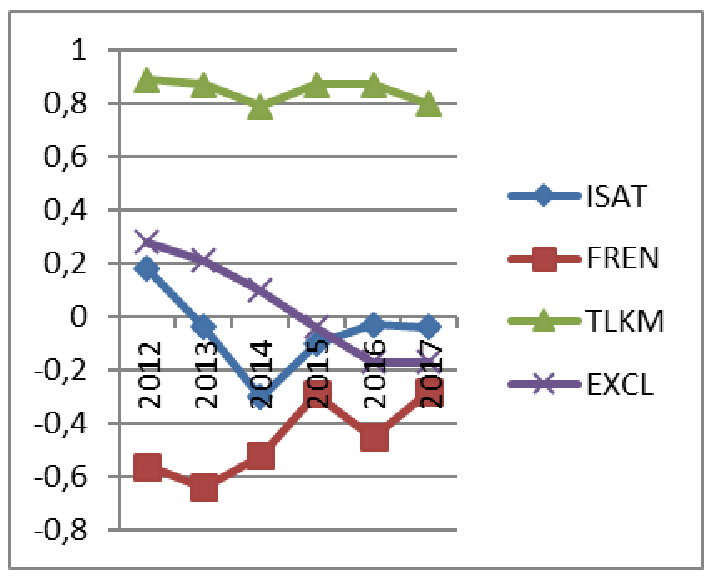

Fig.2. G-Score Growth Chart

From the figure above, it could be seen that from 2012 to 2013 the G-Score of all companies had decreased. The company with the highest decrease in G-Score was owned by PT Indosat Tbk. And the company with the lowest G-Score was owned by PT Smartfren Telecom Tbk and the highest G-Score was owned by PT Telekomunikasi Indonesia Tbk.

From 2013 to 2014, the performance of telecommunication companies increased compared to the previous year. This could be seen from the number of companies with incrasing G-Score than decreasing G-Score. The increasing G-Score was owned by PT Smartfren Telecom Tbk, while the decreasing G-Score was owned by PT Indosat Tbk, PT Telekomunikasi Indonesia Tbk, and PT XL Axiata Tbk. The company with the highest decreasing G-Score was owned by PT Indosat Tbk. While company with the lowest G-Score was owned by PT Smartfren Telecom Tbk and the highest G-Score was owned by PT Telekomunikasi Indonesia Tbk .

From 2014 to 2015, the performance of telecommunication companies continued to increase compared to previous years. This could be seen from the number of telecommunication companies with incrasing G-Score than decreasing G-Score. The increasing G-Score was owned by PT Indosat Tbk, PT Smartfren Telecom Tbk, PT Telekomunikasi Indonesia Tbk while the decreasing G-Score was owned by PT XL Axiata Tbk. Company with the lowest G-Score was owned by PT Smartfren Telecom Tbk. The company with the highest G-Score was owned by PT Telekomunikasi Indonesia Tbk.

From 2015 to 2017, the performance of telecommunication companies declined compared to previous years. This could be seen from the number of telecommunication companies with decreasing G-Score rather than increasing G-Score. The increasing G-Score was owned by PT Indosat Tbk, while the decreasing G-Score was owned by PT Smartfren Telecom Tbk, PT XL Axiata Tbk and PT Telekomunikasi Indonesia Tbk. The lowest G-score was owned by PT Smartfren Telecom Tbk. The company with the highest G-Score was still owned by PT Telekomunikasi Indonesia Tbk.

Based on the description above, it could be concluded that in 2017 the companies predicted to go bankrupt were PT Indosat Tbk, PT Smartfren Telecom Tbk, PT XL Axiata Tbk whereas the company predicted not to go bankrupt was Indonesian Telecom Company. 


\section{Conclusion}

Based on the findings of research and discussion, the conclusion in this study was as follows:

1. In 2012, the companies predicted not to go bankrupt were PT Indosat Tbk, PT Telekomunikasi Indonesia Tbk, and PT XL Axiata Tbk, while the company predicted to go bankrupt was PT Smartfren Telecom Tbk.

2. From 2013 to 2014, the companies predicted not to go bankrupt were PT Telekomunikasi Indonesia Tbk and PT XL Axiata Tbk, while the companies predicted to go bankrupt were PT Indosat Tbk and PT Smartfren Telecom Tbk .

3. From 2015 to 2017 , the company predicted not to go bankrupt was PT Telekomunikasi Indonesia Tbk, while the companies predicted to go bankrupt were PT Indosat Tbk, PT Smartfren Telecom Tbk, and PT XL Axiata Tbk.

4. The number of telecommunication companies predicted to experience bankruptcy continued to increase in the last five years.

\section{Suggestion}

Based on the conclusion in this study, the writers want to give the following suggestions:

1. To the Company:

a. Improving the company's ability to produce net working capital, so that the company is able to pay short-term liabilities using its current assets and avoid bankruptcy.

b. Improving the company's ability to generate profits before interest and net income tax, so that the company avoids bankruptcy.

c. Predicting bankruptcy especially by using the Grover method to find out the probability of a company going bankrupt or not.

d. Maintaining and improving performance so the company avoids bankruptcy

2. To the next researchers:

a. Adding the number of samples, the research period, the characteristics of the industry to be sampled and using other prediction models in order to get better research results.

\section{References}

[1] Altman, Edward I, P. N. (1997) An International Survey of Business Failure Classification Models.

[2] Aminian, A. (2016) 'Investigate the Ability of Bankruptcy Prediction Models of Altman and Springate and Zmijewski and Grover in Tehran Stock Exchange', 7(4), pp. 208-214. doi: 10.5901/mjss.2016.v7n4s1p208.

[3] Dewi Anggraini, M. H. (2017) 'FINANCIAL DISTRESS PREDICTION IN INDONESIA COMPANIES: FINDING AN ALTERNATIVE MODEL', Russian Journal of Agricultural and Socio- Economic Sciences, 1(January), pp. 29-38.

[4] Espacios, H. R., Autores, L. O. S. and Pakdaman, H. (2018) 'Investigating the Ability of Altman and Springate and Zmijewski and Grover Bankruptcy Prediction Models in Tehran Stock Exchange'.

[5] Fatmawati, M. (2012) 'PENGGUNAAN THE ZMIJEWSKI MODEL , THE ALTMAN MODEL , DAN THE SPRINGATE MODEL SEBAGAI PREDIKTOR DELISTING', 16(1). 
[6] Fredy, H. (2018) 'THE PREDICTION OF BANKRUPTCY IN THE PULP AND PAPER INDUSTRY COMPANY LISTED IN INDONESIA STOCK EXCHANGE ON 2011-2016 PERIOD USING Z-SCORE', South East Asia Journal Of Contemporary Business, Economics and Law, 15(5), pp. 52-62.

[7] Husein, M. F. and Pambekti, G. T. (2014) 'Precision of the models of Altman , Springate, Zmijewski, and Grover for predicting the financial distress', 17(3), pp. 405-416. doi: 10.14414/jebav.14.1703010.

[8] Jabeur, S. Ben (2017) 'Bankruptcy prediction using Partial Least Squares Logistic Regression', Journal of Retailing and Consumer Services. Elsevier Ltd, 36(November 2016), pp. 197-202. doi: 10.1016/j.jretconser.2017.02.005.

[9] Nirmala, R. (2016) 'Tanda- tanda Perusahaan Akan Bangkrut', Beritagar.id.

[10] Nugroho, R. E. (2018) 'Analyzing The Potential Bankruptcy of Sharia Life Insurance Companies In Indonesia', International Journal of New Technology and Research (IJNTR), (10), pp. 54-61.

[11] Prihantini, N. M. E. dan M. M. R. S. (2013) 'Prediksi Kebangkrutan dengan Model Grover, Altmant Z- score, Springate dan Zmijewski Pada Perusahaan Food and Beverage di Bursa Efek Indonesia', Akuntansi Universitas Udayana, 5(2), pp. 417435.

[12] Primasari, N. (2018) 'ANALYSIS ALTMAN Z-SCORE , GROVER SCORE , SPRINGATE AND ZMIJEWSKI AS FINANCIAL DISTRESS SIGNALING ( Empirical study of consumer goods industry in Indonesia ) SPRINGATE AND ZMIJEWSKI', (July 2017). doi: 10.13140/RG.2.2.34759.39844.

[13] Puspitasari, D. S. putri (2018) 'COMPARISON OF BANKRUPTCY PREDICTION MODELS ANALYSIS ( ALTMAN, SPRINGATE , GROVER , OHLSON AND ZMIJEWSKI ) ON', Economis and Accounting Journal, 1(2).

[14] Salim, M. N. (2017) 'A N A NALYSIS OF B ANKRUPTCY L IKELIHOOD ON C OAL M INING L ISTED F IRMS IN THE I NDONESIAN S TOCK E XCHANGE : A $\mathrm{N}$ A LTMAN, S PRINGATE AND Z MIJEWSKI A PPROACHES', Eurasian Journal of Economics and Finance, 5(3), pp. 99-108. doi: 10.15604/ejef.2017.05.03.008.

[15] Warastuti, Y., Lucky, E. and Sitinjak, M. (2014) '2014 ANALYSIS OF MODELBASED PREDICTION OF BANK BANKRUPTCY IN THE BANKING COMPANIES LISTED IN INDONESIA STOCK EXCHANGE 2008-2012', 5(1), pp. $71-80$ 